\title{
Genetic diversity of bushy cashew (Anacardium humile A. St.-Hil.) based on characteristics of fruits
}

\author{
Laísse Danielle Pereira ${ }^{1}$, Danielle Fabíola Pereira da Silva², Lásara Kamila Ferreira de Souza ${ }^{3}$, \\ Erick Tiago Lino Pereira ${ }^{4}$, Hildeu Ferreira da Assunção ${ }^{2}$, Marcelo Marques Costa ${ }^{2}$
}

\begin{abstract}
Knowledge of the genetic variability among genotypes of bushy cashew is important to establish strategies for pre-breeding and use in breeding program. The objective of this study was to evaluate the genetic diversity of bushy cashew by means of the evaluation of physical, chemical and physicochemical characteristics of cashew apples and cashew nuts. The work was carried out with cashew nuts and cashew apples collected in the harvest of 2016 of genotypes in the "ex situ" biological collection of Anacardium humile A. St.-Hil. in the area of genetic resources of the Universidade Federal de Goiás - Regional Jataí. The results were submitted to descriptive analysis and multivariate analysis, estimating the mean Euclidean distance obtained from the fruiting attributes analyzed. The measure of similarity and custering of the provenances was done by the optimization algorithm of Tocher and dendrograma UPGMA. There was a coincidence of clusters, which confirms the distribution of genetic diversity of the genotypes in the germplasm bank of Anacardium humile A. St.-Hil. evaluated. The results obtained can be used for the selection of individuals of the species in future works of breeding and conservation of the specie.

Index Terms: Anacardiaceae, germoplasm bank, multivariate analysis.

\section{Diversidade genética de Cajuzinho-do-cerrado (Anacardium humile A. St.-Hil.) com base nas características dos frutos}

Corresponding author: laissedaniellep@gmail.com

Received: April 05, 2019 Accepted: July 11, 2019

Copyright: All the contents of this journal, except where otherwise noted, is licensed under a Creative Commons Attribution License.

\section{(cc) E'}

Resumo - O conhecimento da variabilidade genética entre genótipos de Cajuzinho-do-cerrado é importante para estabelecer estratégias de pré-melhoramento e uso em programa de melhoramento. Objetivou-se com este trabalho avaliar a diversidade genética de Cajuzinho-do-cerrado por meio da avaliação de características físicas, químicas e físico-química de frutos e pseudofrutos. $\mathrm{O}$ trabalho foi realizado com frutos e pseudofrutos coletados na safra de 2016 dos genótipos da coleção biológica "ex situ" de Anacardium humile A. St.-Hil. na área de recursos genéticos da Universidade Federal Goiás - Regional Jataí. Os resultados foram submetidos à análise descritiva e à análise multivariada estimando-se a distância euclidiana média obtida a partir dos atributos da frutificação analisados. A medida de similaridade e agrupamento das procedências foi feita pelo algoritmo de otimização de Tocher e dendrograma UPGMA. Houve coincidências entre os agrupamentos, o que confirma a distribuição da diversidade genética dos genótipos no banco de germoplasma de Anacardium humile A. St.-Hil. avaliado. Os resultados obtidos podem ser utilizados para a seleção de indivíduos da espécie em futuros trabalhos de melhoramento e conservação da espécie. Termos para indexação: Anacardiaceae, banco de germoplasma, análise multivariada.

\footnotetext{
${ }^{1}$ Engenheira Agrônoma, Doutoranda do Programa de Pós-graduação em Ciências Agrárias - Agronomia do Instituto Federal de Educação, Ciência e Tecnologia Goiano - campus Rio Verde, Rio Verde, Goiás, Brasil. E-mail: laissedaniellep@gmail.com (ORCID 0000-0002-2977-3870)

${ }^{2}$ Engenheiro (a) Agrônomo (a), Dr. Professor (a)- Unidade Acadêmica Especial de Ciências Agrárias - Universidade Federal de Goiás - Regional Jataí, Jataí, Goiás, Brasil. E-mails: daniellefpsilva@gmail.com ${ }^{\text {(ORCID 0000-0001-7366-5650) }}$; hildeu@ufg.br ${ }^{\text {(ORCID 0000-0002-4203-6568) }}$;marcelo. marques.costa@gmail.com ${ }^{\text {(ORCID 0000-0001-7386-4262) }}$

${ }^{3}$ Engenheira Florestal - Bolsista CAPES, Mestranda do Programa de Pós-graduação em Agronomia - Universidade Federal de Goiás - Regional Jataí, Jataí, Goiás, Brasil. engekah.lk@gmail.com (ORCID 0000-0002-6914-9853)

${ }^{4}$ Acadêmico de Agronomia do Centro Universitário de Anápolis - UniEVANGÉLICA, Anápolis, Goiás, Brasil. ericktiagolinopereira@gmail. COM $^{\text {(ORCID } 0000-0001-6632-4583)}$
} 
Brazil stands out as one of the main centers of genetic diversity of wild fruit trees in the world (SANTOS \& SANTOS JUNIOR, 2015), being the Brazilian Savannah a ecosystem in renewable natural resources, with fruit species with peculiar characteristics (AVIDOS \& FERREIRA, 2000; MORZELLE, 2015). Considering that native species are well adapted to the local environment, low impact management for seeds collection coupled with the development and proper cultivation practices could bring economic, social and environmental benefits (SOUZA et al., 2018).

Among the innumerable native fruit trees that have high potential for commercial exploitation, it could be emphasized the bushy cashew (Anacardium humile A. St.- Hil.). This specie is a source of energy in food and medicinal use, but is at risk of extinction due to the impact caused by the fragmentation of their populations, either by inadequate extraction or by the expansion of agricultural frontiers (SILVA et al., 2001).

The identification and correct characterization of the genetic diversity of a species is the initial step for its subsequent use in a plant breeding program, which may result in economic gains (DANNER et al., 2011; DANTAS et al., 2012). The conservation of the diversity being is initial points in the domestication of vegetables (DANTAS et al., 2012).

Several methods can be used in the evaluation of genetic diversity, whose choice is based on the precision desired by the researcher, the way the data were obtained and the ease of analysis (RODRIGUES et al., 2010). The techniques of multivariate analysis have been routinely used because they simultaneously consider the evaluated characteristics of the genotypes, in addition to the correlation between them (CONDÉ et al., 2010). Among the multivariate statistical techniques, the principal component analyzes, canonical variables and agglomerative methods (CRUZ et al., 2012).

The volume of studies still incipient on the species opens possibilities for research in order to know its needs to plan future strategies of preservation and use of the specie. Therefore, the objective of this study was to evaluate the genetic diversity between genotypes based on the physical, chemical and physico-chemical characteristics of cashew apple and cashew nut of bushy cashew.

The study was conducted using material obtained from the Biological Collection "ex situ" of Anacardium humile A. St.-Hil, in the area of Genetic Resources of the Universidade Federal de Goiás - Regional Jataí. This experimental area has tropical climate classification of savannah (Aw), with rainy period from october to april and dry from may to september. The annual temperature ranges from $13^{\circ} \mathrm{C}$ to $32^{\circ} \mathrm{C}$ and the annual rainfall of $1700 \mathrm{~mm}$.

Cashew apples and cashew nuts were harvested from 27 genotypes. From each genotype were collected from 5 to 15 units, according to the production. One of the criteria for harvesting was the coloring of the epidermis of the cashew apple, which should be totally yellow or totally red in color, that is, completely mature cashew apple.

After harvesting were taken to the laboratory and analyzed for: cashew apple mass (AM) and cashew nut (NM) mass in digital scale, expressed in grams; cashew apple length (AL), cashew apple base diameter (ABD), cashew apple apex diameter (AAD), cashew nut length (NL), cashew nut width (NW), cashew nut thickness (NT) being determined in millimeters using a pachymeter. The color of the epidermis of the cashew apple (measured in the equatorial region of one of the faces of the cashew apple) was given by the coordinate $\mathrm{C}^{*}$ (CEA) and angle hue or $\mathrm{h}^{\circ}$ (hEA), and pulp through, also, by the coordinate $\mathrm{C}^{*}$ (CPA) and $\mathrm{h}^{\mathrm{o}}$ (hPA) determined using a colorimeter Konica Minolta, model CR-10. This equipment measures reflected light, using a Cartesian coordinate system $\mathrm{L}^{*}$, $a^{*}$ and $b^{*}$, of which units or points of approximate visual uniformity are obtained (KONICA MINOLTA, 2018).

The cashew apple were also analyzed for soluble solids content (SS) using a portable refractometer, expressed in ${ }^{\circ} \mathrm{Brix}$; to the titratable acidity (TA) by titrations under stirring with $0.1 \mathrm{~N} \mathrm{NaOH}$ solution using $1 \%$ phenolphthalein as indicator, expressed in $\%$ of citric acid; soluble solids ratio and acidity (ratio) was obtained by dividing the soluble solids values by the titratable acidity content, and the vitamin C (VIT C) determined by titration with Tillman's reagent $[2,6$ dichloropheno-indofenol (sodium salt) to 0,1\%] (AOAC, 2016), expressed in mg of ascorbic acid/ $100 \mathrm{~g}$ of pulp and carotenoids (CRT) which were extracted with acetone and analyzed in a refractometer, the absorbances were determined in 470, 646,8 e 663,2 $\mathrm{nm}$ and the levels of carotenoids determined according to the equations of Lichtenthaler (1987) and expressed in \%.

The results were submitted to descriptive analysis, obtaining mean, minimum, maximum and coefficient of variation $(\mathrm{CV})(\%)$; and relative importance of the characters for total variation (S.j) (\%), using the criterion proposed by Singh (1981).

It was also used to the multivariate analysis by estimating the mean Euclidean distance obtained from the 27 bushy cashew genotypes, evaluated on the basis of the fruiting attributes analyzed. The measure of similarity and clustering of the accessions was made by the algorithm of optimization of Tocher and dendrogram UPGMA (Unweighted Pair Group Method using Arithmetic averages) (CRUZ et al., 2012).

The cut off criterion used to determine the number of groups in the UPGMA method was based on the relative size of the 27 levels of fusions (MOJENA, 1977). The cophenetic correlation coefficient (CCC) was calculated between the genetic dissimilarity matrix and the matrix of the cophenetic values, in order to verify the consistency of the cluster. 
Data analyzes were performed with the aid of the GENES computer program (CRUZ, 2013). The dendrogram was made with the aid of software Statistic, versão 5.0.

The variables measured to determine the diversity contained in the accesses of the germplasm bank obtained coefficient of variation values ranging from 8.969 to $50.258 \%$ (Table 1), indicating that these variables present different degrees of heterogeneity. There was no discrepancy between the values of the relative contribution of the variables to genetic dissimilarity, was relatively well distributed, varying from 2.998 to $9.431 \%$. The soluble solids content $(9.431 \%)$, cashew apple length $(8.508 \%)$ and the $\mathrm{C} *$ coordinate of the epidermis of the cashew apple $(8.337 \%)$ were the variables that contributed most to total variation (or genetic dissimilarity).

According to Cruz et al. (2012), the relative importance of the characters helps in discarding variables, enabling a better choice of attributes to be considered in a genetic divergence assessment. However, in the present work it is not possible to discard variables, since both have S.j (\%) with close values.

The UPGMA dendrogram (Figure 1) discriminated six groups among the 27 genotypes studied, showing access 1 allocated separately, while the other genotypes were divided into the other groups. This difference between access 1 and the others can also be observed in the Tocher cluster (Table 2), which generated two groups, where genotype 01 occupied one group while the others grouped together.

The groups of UPGMA were divided by the cut off point of 0.293 , which equals $55 \%$ of the distance, forming six groups. The clustering provided by this method was adequate for the representation of the genetic divergence and group formation between the accesses used for presenting co-expressed correlation (CCC) equal to 0.81 . This coefficient measures the fit between the dissimilarity matrix and the simplification matrix, due to the clustering method and can be used to increase the reliability of the conclusions regarding the interpretation of dendrograms (CRUZ et al., 2012).

For Monteiro et al. (2010), the closer to the unit is the cophenetic correlation coefficient, the better the dissimilarity matrix representation in the dendrogram form. This makes it possible to make inferences through the analyzed variables and revealing a good fit between the graphic representation of the distances and their original matrix, reinforcing the reliability of the results. CCC values above 0.80 indicate good representativity between distances (CRUZ et al., 2011).

In order to better verify the diversity by the Tocher method, access 1 was removed and a new clustering was done (Table 3), where six groups were formed. The acess 1 was mainly differentiated in characters related to coloration, where it had reddish epidermis $(\mathrm{hEA}=9.70)$, while the others had a yellowish coloration (hEA : 9.70); and the larger dimensions of cashew nut (NL: $22.70 \mathrm{~mm}$, NW: $22.63 \mathrm{~mm}, \mathrm{NT}: 13.70 \mathrm{~mm}$ and NM: $3.57 \mathrm{~g})$. They are group 1 that contains 14 genotypes $(05,15,26,10$, $19,21,13,23,07,11,14,04,16,09)$ that, did not present higher mean values in relation to the other groups in any of the characters, corresponds to a genotype of group 2 and the highest part of the genotypes that make group 3 of UPGMA, with the exception of genotypes 08 and 18, which together with genotype $03(08,18,03)$ of group 4 of UPGMA set group 2 stood out characters ratio (11.33 - 13.78) and NL (13.67 - $17.60 \mathrm{~mm})$; group $3(20,25,17)$ corresponds to group 5 of UPGMA and stood out in the mean values of the variables AL $(32.04-37.92 \mathrm{~mm})$ and CRT (0.20-0.48\%); group 4 with SS (12.40- $13.00^{\circ}$ Brix $)$ and VITC (102.84-279.64 mg of ascorbic acid / 100g of pulp) in contrast and results from two genotypes present in group 4 of UPGMA $(12,22)$; group 5 presented higher in the mean values of the AT $(1.41-1.64 \%)$ results from two genotypes from group 2 of the UPGMA $(02,06)$; and group 6 corresponds to group 6 of the UPGMA (24, 27), which presented larger dimensions of cashew apple (ABD: $20.80-21.10 \mathrm{~mm}$, AAD: $31.82-33.95 \mathrm{~mm}$ and AM: $12.16-18.78 \mathrm{~g}$ ) and cashew nut (NW: $15.31-16.50$ $\mathrm{mm}, \mathrm{NT}: 12.79-12.93 \mathrm{~mm}$ and NM: $1.84-2.75 \mathrm{~g})$.

Vasconcelos et al. (2007) emphasize that the Tocher method presents the peculiarity of gathering a greater number of genotypes in the first groups and generally individuals in isolation in the last groups. In this type of study, this characteristic of the method becomes interesting, since it allows identifying genetically dissimilar individuals and not only groups.

The coincidence of clusters confirms the distribution of the genetic diversity of the genotypes in the germplasm bank evaluated. However, it shows that the genotypes grouped in the same group have similar characteristics among them, being able to later select for maintenance and / or future use only some genotypes that prove to be more productive and / or based on molecular analyzes.

This study showed genetic variability within the studied population of Anacardium humile A. St.-Hil. The results obtained can be used for the selection of individuals of the species in future works of breeding and conservation of the species. 
Table 1- Average, minimum, maximum, coefficient of variation (CV) and relative contribution ( $\mathrm{Sj}$ ) of the traits, for the dissimilarity of the genotypes of bushy cashew

\begin{tabular}{cccccc}
\hline Traits & Average & minimum & maximum & CV $(\%)$ & S. j (\%) \\
\hline AL & 24.432 & 16.505 & 37.918 & 24.646 & 8.508 \\
ABD & 15.208 & 9.424 & 21.105 & 18.385 & 6.165 \\
AAD & 24.345 & 17.578 & 33.949 & 16.221 & 6.261 \\
AM & 7.345 & 2.179 & 18.779 & 50.258 & 5.468 \\
NL & 15.465 & 11.990 & 22.700 & 13.190 & 3.903 \\
NW & 14.583 & 11.513 & 22.627 & 14.084 & 3.674 \\
NT & 11.437 & 9.349 & 13.692 & 8.969 & 6.003 \\
NM & 1.419 & 0.626 & 3.575 & 42.141 & 4.421 \\
SS & 9.027 & 5.287 & 13.000 & 25.297 & 9.431 \\
AT & 1.137 & 0.657 & 1.652 & 22.241 & 6.943 \\
ratio & 8.173 & 3.877 & 13.78 & 33.340 & 8.146 \\
VITC & 137.971 & 74.086 & 279.643 & 33.214 & 5.347 \\
CRT & 0.235 & 0.103 & 0.479 & 33.298 & 4.667 \\
CEA & 39.962 & 30.333 & 49.233 & 13.165 & 8.337 \\
hEA & 82.060 & 9.700 & 101.067 & 22.267 & 4.303 \\
CPA & 27.693 & 10.367 & 43.000 & 26.463 & 5.426 \\
hPA & 98.668 & 49.633 & 114.033 & 10.896 & 2.998 \\
\hline
\end{tabular}

AL: cashew apple length (mm); ABD: cashew apple base diameter (mm); AAD: cashew apple apex diameter (mm); AM: cashew apple mass (g); NL: cashew nut length (mm); NW: cashew nut width (mm); NT: cashew nut thickness (mm); NM: cashew nut mass (g); SS: content soluble solids of the cashew apple (\%); TA: content titratable acidity of the cashew apple (\% citric acid); ratio: soluble solids / titratable acidity; VITC: content vitamin $\mathrm{C}$ of the cashew apple (mg of ascorbic acid / 100g of pulp); CRT: content carotenoids of the cashew apple (\%); CEA: C * coordinate of the cashew apple epidermis; hEA: hue angle of the epidermis of the cashew apple $\left(\mathrm{h}^{\mathrm{o}}\right)$; CPA: coordinate $\mathrm{C} *$ of the pulp of the cashew apple; hPA: hue angle of the pulp of the cashew apple $\left(h^{\circ}\right)$.

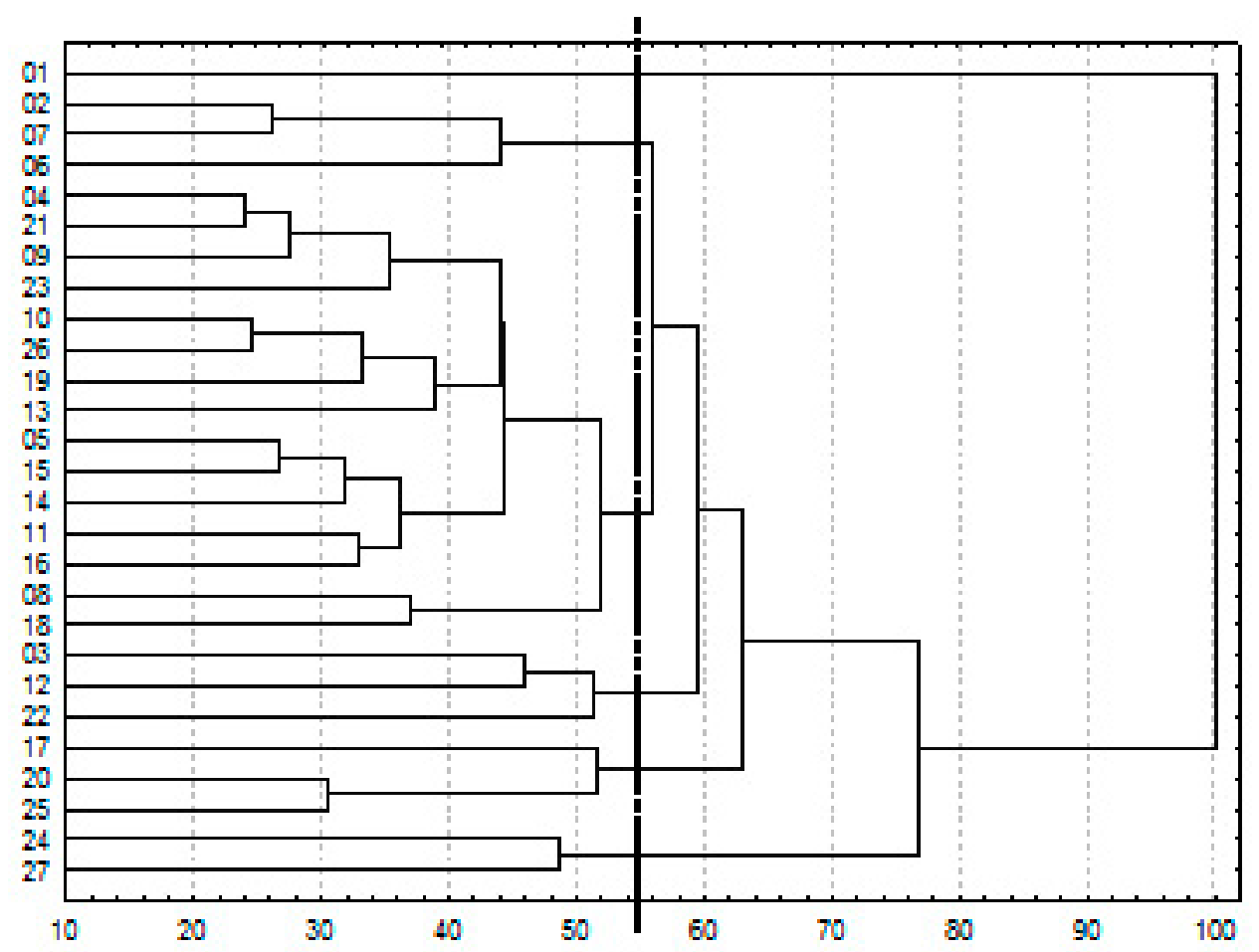

Figure 1- Dendrogram generated by the UPGMA method from dissimilarities expressed by mean Euclidean distance between 27 genotypes of bushy cashew, from 17 cashew nut and cashew apple traits. Coefficient of Cophenetic Correlation (CCC): 0.81 
Table 2. Groups established by the Tocher method, based on the 17 traits for 27 genotypes of bushy cashew

\begin{tabular}{|c|c|}
\hline Group & Genotype \\
\hline \multirow{3}{*}{1} & $\begin{array}{llllllllllll}04 & 21 & 9 & 23 & 05 & 15 & 26 & 19 & 11 & 10 & 13 & 07\end{array}$ \\
\hline & $\begin{array}{lllllllllll}16 & 14 & 08 & 02 & 18 & 25 & 12 & 03 & 20 & 22 & 17\end{array}$ \\
\hline & $27 \quad 06 \quad 24$ \\
\hline 2 & \\
\hline
\end{tabular}

Table 3. Groups established by the Tocher method, based on the 17 traits for 26 genotypes of bushy cashew

\begin{tabular}{ll}
\hline \multicolumn{1}{c}{ Group } & \multicolumn{1}{c}{ Genotype } \\
\hline 1 & 051526101921132307111404 \\
2 & 1609 \\
3 & 081803 \\
4 & 202517 \\
5 & 1222 \\
6 & 0206 \\
\hline
\end{tabular}

\section{Acknowledgments}

The authors thank the Coordination for the Improvement of Higher Education Personnel (CAPES), National Council for Scientific and Technological Development (CNPq) and Coordenação de Pesquisa e Inovação (COPI) da Universidade Federal de Goias Regional Jataí for the financial support.

\section{References}

AOAC - Official methods of analysis of the Associationof Official Analytical Chemists International. $20^{\text {th }}$ ed. Washington: Patricia Cunniff, 2016, p. 945- 989.

AVIDOS, M. F. D.; FERREIRA, L. T. Frutos dos cerrados: preservação gera muitos frutos. Biotecnologia Ciência e Desenvolvimento, Brasília, v.3, n.15, p36-41, 2000

CONDÉ, A. B. T.; COELHO, M. A. O.; FRONZA, V.; SOUZA, L. V. Divergência genética em trigo de sequeiro por meio de caracteres morfoagronômicos. Revista Ceres, Viçosa, v. 57, n. 6, p. 762-767, 2010.

CRUZ, C. D.; FERREIRA, F. M.; PESSONI, L. A. Biometria aplicada ao estudo da diversidade genética. Visconde do Rio Branco: Suprema, 2011, 620p.

CRUZ, C. D.; REGAZZI, A. J.; CARNEIRO, P. C. S. Modelos biométricos aplicados ao melhoramento genético. $4^{\text {th }}$ ed. Viçosa: UFV, 2012, 514p.
CRUZ, C. D. GENES - a software package for analysis in experimental statistics and quantitative genetics. Acta Scientiarium, Maringá, V. 35, n. 3, p.271-276, 2013.

DANNER, M. A.; CITADIN, I.; SASSO, S. A. Z; SCARIOT, S.; BENIN, G. Genetic Dissimilarity Among Jabuticaba Trees Native to Southwestern Paraná, Brazil. Revista Brasileira de Fruticultura, Jaboticabal, v.33, n. 2, p517-525, 2011.

DANTAS, A. C. A.; NUNES, G. H. S.; ARAÚJO, S. I.; ALBUQUERQUE, L. B. Caracterização molecular de acessos de melão coletados no Nordeste brasileiro. Revista Brasileira de Fruticultura, Jaboticabal, v.34, n.1, p183-189, 2012.

KONICA MINOLTA. Compreendendo o Espaço de Cor CIE $\mathbf{L}^{*} \mathbf{C} * \mathbf{h}$. Disponível em: <http://sensing. konicaminolta.com.br/2015/08/compreendendo-o-espacode-cor-cie-lch/>. Acesso em: 22 de fevereiro de 2018.

LICHTENTHALER, H. K. Chlorophylls and carotenoids: pigment photosynthetic biomembranes. Methods in Enzymology, San Diego, v.148, p. 362-385, 1987.

MOJENA, R. Hierarchical grouping methods and stopping rules: an evaluation. The Computer Journal, Osford, v. 20, p. 359-363, 1977.

MONTEIRO, E. R.; BASTOS, E. M.; LOPES, Â. C. A.; GOMES, R. L. F.; NUNES. J. A. R. Diversidade genética entre acessos de espécies cultivadas de pimentas. Ciência Rural, Santa Maria, v. 40, n. 2, p. 288-293, 2010. 
MORZELLE, M. C. Caracterização química e física de frutos de curriola, gabiroba e murici provenientes do cerrado brasileiro. Revista Brasileira de Fruticultura, Jaboticabal, v.37, n.1, p.96-103, 2015.

RODRIGUES, H.C. de A.; CARVALHO, S.P. de; CARVALHO, A.A. de, FILHO, J.L.S. de C.; CUSTÓDIO, T.N. Avaliação da diversidade genética entre acessos de mamoneira (Ricinus communis L.) por meio de caracteres morfoagronômicos. Revista Ceres, Viçosa, v.57, n. 6, p.773-777, 2010.

SANTOS, R. da C. dos; SANTOS JÚNIOR, J. E. dos. Divergência genética por análise multivariada de caracteres fenotípicos de Anacardium humile (St. Hilaire). Revista Ceres, Viçosa, v. 62, n.6, p. 507-509, 2015.
SILVA, D. B. da; SILVA, J. A. da; JUNQUEIRA, N. T. V.; ANDRADE, L. R. M. de. Frutas do cerrado. Brasília: Embrapa Informações Tecnológica, 179p, 2001.

SINGH, G. Late quaternary pollen records and seasonal palacoclimates of lake frome, South Australia. Hydrobiologia, Netherlands, n. 82, p. 419 - 430, 1981.

SOUZA, R. G.,; DAN, M. L.; DIAS-GUIMARAES, M. A.; GUIMARAES, L.A. O. P.; BRAGA, J. M. Fruits of the Brazilian Atlantic Forest: allying biodiversity conservation and food security. Anais da Academia Brasileira de Ciências, v. 90, n. 4, p. 3583-3595, 2018.

VASCONCELOS, E. S.; CRUZ, C. D.; BHERING, L. L.; RESENDE JUNIOR, M. F. R. Método alternativo para análise de agrupamento. Pesquisa Agropecuária Brasileira, Brasília, v. 42, n. 10, p. 1421-1428, 2007. 